\title{
NEW INEQUALITIES OF THE HERMITE-HADAMARD TYPE FOR n-TIME DIFFERENTIABLE FUNCTIONS WHICH ARE QUASICONVEX
}

\author{
ÇETIN YILDIZ
}

Abstract. In this paper, by using an integral identity and the Hölder integral inequality we establish several new inequalities for $n$-time differentiable mappings that are connected with the Hermite-Hadamard inequality.

Mathematics subject classification (2010): 26D15, 26D10.

Keywords and phrases: Hermite-Hadamard inequality, Hölder inequality, quasiconvex functions.

\section{REFERENCES}

[1] M. Alomari, M. Darus And S. S. Dragomir, New inequalities of Hermite-Hadamard type for functions whose second derivatives absolute values are quasi-convex, Tamkang Journal of Mathematics, 41 (4), 2010, 353-359.

[2] S.-P. BAI, S.-H. WANG AND F. QI, Some Hermite-Hadamard type inequalities for $n$-time differentiable $(\alpha, m)$-convex functions, Jour. of Ineq. and Appl., 2012, 2012:267.

[3] P. Cerone, S. S. Dragomir And J. Roumeliotis, Some Ostrowski type inequalities for $n$-time differentiable mappings and applications, Demonstratio Math., 32 (4) (1999), 697-712.

[4] P. Cerone, S. S. Dragomir And J. Roumeliotis And J. Šunde, A new generalization of the trapezoid formula for $n$-time differentiable mappings and applications, Demonstratio Math., 33 (4) (2000), 719-736.

[5] S. S. Dragomir And C. E. M. Pearce, Selected Topics on Hermite-Hadamard Inequalities and Applications, RGMIA Monographs, Victoria University, 2000, online: http://www.staxo.vu.edu.au/RGMIA/monographs/hermite hadamard.html.

[6] D.-Y. Hwang, Some Inequalities for $n$-time Differentiable Mappings and Applications, Kyung. Math. Jour., 43 (2003), 335-343.

[7] D. A. Ion, Some estimates on the Hermite-Hadamard inequalities through quasi-convex functions, Annals of University of Craiova, Math. Comp. Sci. Ser., 34 (2007), 82-87.

[8] J. L. W. V. JENSEN, On konvexe funktioner og uligheder mellem middlvaerdier, Nyt. Tidsskr. Math. B., 16, 49-69, 1905.

[9] W.-D. JIANG, D.-W. NIU, Y. HUA AND F. QI, Generalizations of Hermite-Hadamard inequality to $n$-time differentiable function which are s-convex in the second sense, Analysis (Munich), 32 (2012), 209-220.

[10] U. S. Kirmaci, M. K. Bakula, M. E. Özdemir And J. Pećarić, Hadamard-type inequalities for s-convex functions, Appl. Math. and Comp., 193 (2007), 26-35.

[11] M. E. ÖZDEMIR AND U. S. KIRMACI, Two new theorem on mappings uniformly continuous and convex with applications to quadrature rules and means, Appl. Math. and Comp., 143 (2003), 269274.

[12] M. E. ÖZdemIR, Ç. YILdIz, New Inequalities for $n$-time differentiable functions, Arxiv: $1402.4959 \mathrm{v} 1$.

[13] M. E. ÖZdEMIR, Ç. YILDIZ, New Inequalities for Hermite-Hadamard and Simpson Type with Applications, Tamkang J. of Math., 44, 2, 209-216, 2013.

[14] M. E. Özdemir, Ç. Yildiz, A. O. Akdemir and E. Set, New Inequalities of Hadamard Type for Quasi-Convex Functions, AIP Conference Proceedings, 1470, 99-101 (2012), doi: 10.1063/1.4747649. 
[15] J. E. PeČarić, F. Porschan And Y. L. Tong, Convex Functions, Partial Orderings, and Statistical Applications, Academic Press Inc., 1992.

[16] A. Saglam, M. Z. Sarikaya And H. Yildirim, Some new inequalities of Hermite-Hadamard's type, Kyung. Math. Jour., 50 (2010), 399-410.

[17] E. Set, M. E. Özdemir AND S. S. Dragomir, On Hadamard-Type Inequalities Involving Several Kinds of Convexity, Jour. of Ineq. and Appl., 2010, 286845.

[18] S. H. WAng, B.-Y. XI AND F. QI, Some new inequalities of Hermite-Hadamard type for $n$-time differentiable functions which are $m$-convex, Analysis (Munich), 32 (2012), 247-262.

[19] B.-Y. XI AND F. QI, Some integral inequalities of Hermite-Hadamard type for convex functions with applications to means, J. Funct. Spaces Appl., 2012 (2012), http://dx.doi.org/10.1155/2012/ 980438. 